\title{
LITA Award, 1980: Maurice J. Freedman
}

\section{S. Michael MALINCONICO}

This is the third presentation of the LITA Award for Outstanding Achievement. The first two honored individuals whose achievements can be said to have created the discipline we know as library automation. The first award went to Fred Kilgour whose vision, daring, and entrepreneurial and managerial skills changed the way libraries operate almost overnight, and may in the increasingly stringent economic times ahead have helped ensure the economic viability of libraries. The second award went to Henriette Avram, whose untiring efforts on behalf of the MARC formats and their promulgation is only just short of legendary.

This year's winner distinguished himself in a somewhat different manner. His contributions did not lead to the development of new automated systems or services. Rather, his outstanding achievement lies in the creative and pioneering use he made of technology in support of a clear vision of effective library service. His contribution comes from the depth of sensitivity and understanding he brought to the application of technology to library service. Much to our good fortune, he has chosen to share with us through his many writings the insights he has found in his study of the fit between technology and the delivery of effective library service.

This year's winner shares the distinction, with the two previous winners, of being a former president of the division.In fact, he presided over the change from the venerable acronym ISAD to the new name of the division: Library and Information Technology Association (LITA).

It gives me particular pleasure to present this year's award, as it goes not simply to an esteemed colleague but to a valued friend. I first met Maurice (Mitch) Freedman at the first ALA conference I attended-the Midwinter Meeting of 1972. The first session I attended at that conference was a meeting of the Committee on Library Automation (COLA). I had gone to that meeting to report on NYPL's automated cataloging system, which had that month become fully operational with the publication of the book catalogs of the research libraries and of the mid-Manhattan library.

Following the COLA program, Mitch approached me, introduced himself, and inquired about the possibility of using the NYPL system to produce Hennepin County's catalog. The consequences of that afternoon were most salutary both for the Hennepin County Library (HCL) and for me personally. HCL acquired at no cost an automated bibliographic control system, and I gained a friendship that has endured for nearly a decade.

Thus, rather than dwelling on Mitch's professional accomplishments-which are already well known to you-I would prefer to say a few words about the man himself. Perhaps the best way to characterize him is to describe to you his office at 


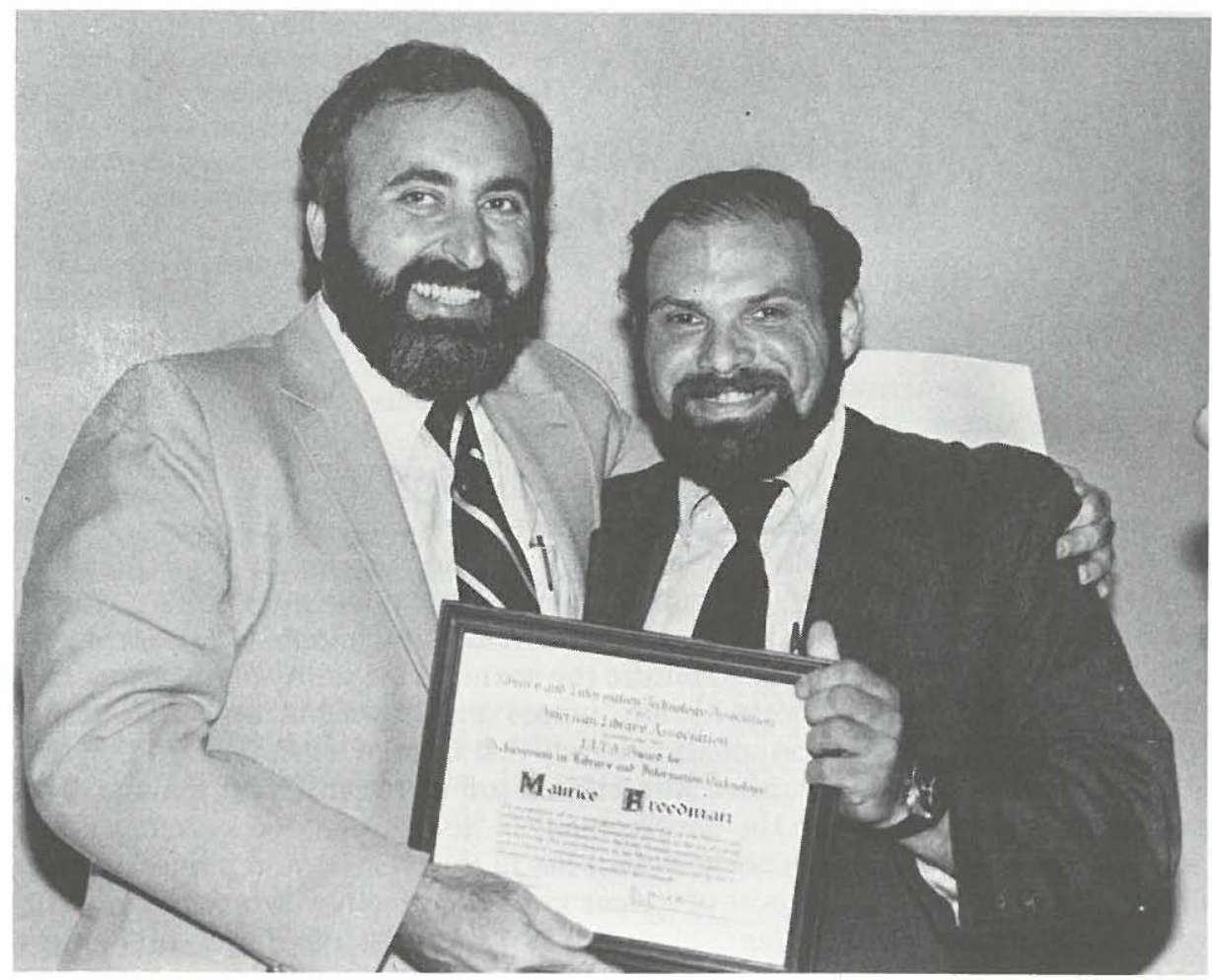

Maurice Freedman (left) receiving 1980 LITA Award presented by S. Michael Malinconico (right).

Columbia University. Prominently displayed on the walls are two enormous posters, one of Bertrand Russell and another of Lenny Bruce. A perhaps odd pair until one realizes that these men had one important attribute in common: neither of them accepted, without incontrovertible proof, truths supported by conventional wisdom alone.

Mitch, like the philosopher and satirist whose images grace the walls of his office, is an iconoclast who insists on more than the endorsement of reigning authority before he will embrace an idea; and he will work tirelessly to change the prevailing wisdom if he finds that it serves to frustrate rather than aid the delivery of the kind and quality of library service to which he feels the patrons of libraries are entitled. Likewise, though he was among the pioneers who helped introduce sophisticated technologies such as automation and micrographics into the operation of libraries, he has always maintained a healthy skepticism, which has prevented him from being seduced by the dry voices of the hollow men who proclaim marvels that are in reality only gilded figures of straw.

Just as Lenny Bruce refused to accept contemporary conventions regarding language and behavior, Mitch Freeman has refused to accept the sanctity of LC subject terminology. He, Sanford Berman, and Joan Marshall have served for more than a decade as LC's conscience, prodding our phlegmatic, de facto national library to action. Just as Bertrand Russell returned to the axioms of Giuseppe Peano in an attempt to secure the foundation of mathematics in formal logic and to 
free that discipline of fuzzy thinking, Mitch has returned to the principles articulated by Antonio Panizzi and Seymour Lubetzky, as the tests by which to judge the claims of the self-assured mountebanks who regale us with newly coined bibliographic wisdom.

In this regard I anxiously await the completion of his doctoral dissertation, in which he explores the philosophical underpinnings of theories of bibliographic control (a work that would have proved most useful during the protracted emotional debate that surrounded AACR2).

I expect that it must be particularly gratifying for Mitch to accept his award in this particular city. Although his physical roots are in the Northeast, I rather think his intellectual and spiritual roots are here, or more precisely, in the city across the bay-Berkeley. It was just about twenty years ago that Mitch, after graduating from Rutgers University, Newark, enrolled as a graduate student in philosophy at the University of California, Berkeley. While at Berkeley, his sense of social justice and utter disdain for unsupported dogma-could one expect less of a student of philosophy? - led him to become active in the free speech movement. Thus, we find very early in his career a concern for social issues, a concern that reemerged in his active involvement with the Social Responsibilities Round Table shortly after joining the library profession.

Before leaving Berkeley, Mitch earned his degree in library science. Thus, he earned his degree from one of the most prestigious library schools on the west coast, and now plies his trade as associate professor at one of the most prestigious library schools on the east coast, the Columbia University School of Library Service. If he is only moderately successful in conveying to his students his dedication to the delivery of quality library service, his steadfast conviction that technical services is in reality the first step in the provision of effective public service, and a respect for the supremacy of principle over expedience, his graduating classes will constitute a more lasting and meaningful award than this simple gesture conferred upon him by his professional colleagues. 